\title{
A Natural Ligand for L-Selectin Is Heparan Sulfate with a Specific Structure
}

\section{L -セレクチンの天然リガンドの一つは特異的構造をもったヘパラン硫酸である}

Norgard-Sumnicht, K. and Varki, A. (1995) J. Biol. Chem., 270, 12012-12024

Key Words: heparan sulfate, heparin, L-selectin, ligand

The selectins (L-, P-, and E-selectin) are a family of calcium-dependent mammalian lectins that initiate interactions between blood cells and endothelial cells. P-and E-selectins are inducible receptors on endothelium that recognize certain sialylated, fucosylated ligands such as sialyl-Lewis ${ }^{X}\left(\operatorname{SLe}^{\mathrm{X}}\right)$ and sialyl-Lewis ${ }^{\mathrm{a}}$ on leukocytes. They participate in the trafficking of these cells to areas of inflammation and injury. In contrast, $\mathrm{L}$-selectin is expressed on leukocytes and recognizes specific carbohydrate ligands on endothelial cells. L-selectin mediates the "homing" of lymphocytes by binding to sialylated, sulfated oligosaccharides on the high endothelial venules (HEVs) of lymph nodes. It has been shown that oligosaccharides generate high affinity ligands for L-selectin by forming unique "clustered saccharide patches" on heavily glycosylated molecules such as mucins. L-selectin is also expressed on neutrophils and monocytes and participates in the emigration of these cells through the endothelium of nonlymphoid tissues. However, no corresponding ligand had been characterized in any endothelial cells from nonlymphoid tissues. The authors introduced here previously demonstrated that natural ligands for L-selectin on nonlymphoid endothelial cells are heparan sulfate proteoglycan (HS-PG) [Norgard-Sumnicht, K.E. et al. (1993) Science, 261, 480-483]. In the paper introduced here, they reported that unusual structures present on HS chains, which have glucosamine residues with unsubstituted amino groups, might account for their specific affinity for L-selectin.

It is known that HS can contain many distinct types of highly sulfated domains, generated by different patterns of sulfation and epimerization, and interacts with numerous molecules, including selectins, growth factors, enzymes, and extracellular matrix proteins etc., through the highly sulfated domains. The pentasaccharide sequence responsible for the high affinity binding of heparin to antithrombin III is a specific sequence which includes a unique 3-O-sulfate group. HS which binds to bFGF contains repeating $\operatorname{IdoA}(2-O-S)$-GlcNS disacchaide sequences with few 6-O-sulfate groups and it appears that both the 2-O- and $\mathrm{N}$-sulfate groups are essential for the binding activity. In contrast, a high content of the 6-Osulfate groups is required for its specific interaction with aFGF and FGF-4 [Ishihara, M. (1994) Glycobiology, 4, 817-824].

Furthermore, the binding of HS to hepatocyte growth factor seems to involve unique domains with predominantly
セレクチン(L-、P-、E-セレクチン)はカルシウム依存性の動 物レクチン群の仲間で、白血球細胞と内皮細胞の相互作用を引 き起こす。P-とE-セレクチンは活性化した内皮細胞上に発現 し、白血球上のシアリルールイス ${ }^{x}\left(\mathrm{SLe}^{\mathrm{x}}\right)$ やシアリルールイス $\mathrm{a}$ の ようなシアル酸やフコースを含んだ糖鎖をリガンドとして認識 する。この相互作用は傷害を受けた炎症サイトへの白血球の誘 導に関与している。これに対し、L-セレクチンは白血球上に発 現し、内皮細胞の特異的糖鎖リガンドと相互作用をする。たと えば、L-セレクチンをもったリンパ球はリンパ節の高内皮細静 脈(HEV)上のシアル酸や硫酸基を含んだオリゴ糖との結合によ り、リンパ節にホーミングする。L-セレクチンと高い親和性を もつリガンドはムチン様分子上にこれらのオリゴ糖鎖が多数結 合して生じる糖鎖のクラスターパッチが形成されている必要が ある。L-セレクチンは好中球や単球上にも発現されており、リ ンパ組織以外の血管内皮へのこれらの血球の誘導にも関与して いる。しかしながら、リンパ組織以外の内皮細胞からはL-セレ クチンのリガンドは同定されていなかった。ここで紹介した著 者たちは、以前りンパ組織以外の内皮細胞上のL-セレクチンの リガンドはヘパラン硫酸プロテオグリカン(HS-PG)であることを 示した[Norgard-Sumnicht, K.E. et al. (1993) Science, 261,480483]。ここで紹介する論文では、彼らはL-セレクチンとの結合 性はHSの中の非置換アミノ基をもつグルコサミン残基を含んだ 特異的な構造によると報告している。

HSは硫酸化やエピマー化度の異なる様々な高硫酸化ドメイ ンを含んでいることが知られており、セレクチン、増殖因子、 酵素類、細胞外基質タンパク質など多くの分子がこの硫酸化ド メインを介して相互作用をしている。例えば、アンチトロンビ ンIII 強く結合する五糖鎖構造は3-O-硫酸基を含む特異的な糖 鎖配列をもつ。bFGFと結合するHSは繰り返しのIdoA(2-O-S)GlcNS配列を含んでいて、2-O-とN-硫酸基の両方が必須であり、 6-O-硫酸基は少ない。これに対して、aFGFやFGF-4との特異的 相互作用には6-O-硫酸基が必要である[Ishihara，M. (1994) Glycobiology, 4, 817-824]。

さらに肝細胞增殖因子との結合には硫酸基をもたないイズ 
non-sulfated iduronates, and the highest affinity seems to be most closely associated with 6-O-sulfate groups. Thus, the presence of various $O$-sulfate groups in addition to $N$-sulfate groups in the highly sulfated domains of HS can provide specific affinity to each protein.

Current understanding of the biosynthesis of heparin/HS indicates that all amino groups of glucosamine residues must be either $\mathrm{N}$-sulfated or $\mathrm{N}$-acetylated. However, the authors demonstrated the presence of some unsubstituted amino groups in HS from both bovine and human endothelial cells, but not from $\mathrm{CHO}$ cells by reactivities with nitrous acid and with sulfo- $N$ hydroxysuccinimide-biotin. The novel structures with unsubstituted amino groups were enriched in HS chains which bound to $\mathrm{L}$-selectin in a calcium-dependent manner. It is very interesting that commercial heparin contains far fewer structures that can bind with high affinity to L-selectin than HS from endothelial cells. Heparin generally contains much higher sulfate groups and iduronate residues than HS, but few unsubstituted amino groups. It appears likely that endothelial HS carries specific sequences with unsubstituted amino group mediating L-selectin recognition that are not found in heparin. The authors did not show any carbohydrate sequences and domain structures including patterns of sulfation, and epimerization. However, the paper added an important aspect that unsubstituted amino groups may be more common than previously recognized and represent another way in which heparin/ HS can mediate specific biological functions.

Fragments from commercial heparin as small as tetrasaccharides could block L- and P-selectin binding to $\mathrm{SLe}^{\mathrm{x}}$-bovin serum albumin, at concentrations far lower than those required for $\mathrm{SLe}^{\mathrm{X}}$ itself [Nelson, R.M. et al. (1993) Blood, 82, 3253-3258]. Thus, heparin/HS with the specific structure may be another type of high affinity natural ligand for the selectins. Future studies will, no doubt, focus on investigations of domain strucutre including the unsubstituted amino groups in heparin/HS involved in the binding of selectins and on regulations for formation of the unique domain structures of HS. From a pharmaceutical perspective, these heparin-like molecules might potentially be more useful than the sialylated, fucosylated polylactosamines with regard to use as therapeutic blockers for selectins.

\section{Reported by Ishihara, M.}

\section{Seikagaku Corporation}

Tokyo Research Institute

Higashiyamato-shi, Tokyo, 207

Japan
ロン酸を多く含むドメインが関与し、この結合性は6-O-硫酸基 の含量と深く関連している。このように、HSの高硫酸化ドメイ ンにおける $\mathrm{N}$-硫酸基と様々なO-硫酸基の存在がそれぞれの夕ン パク質との特異的結合性を与えている。

現在ヘパリン/HSの生合成の過程で、グルコサミン残基の すべてがN-硫酸化あるいはN-アセチル化されていると理解され ている。しかし、この著者たちはウシやヒトの内皮細胞から調 製したHSは非置換アミノ基が存在することを亜硝酸分解やンル ホ-N-ヒドロキシスクシンイミドービオチン法を用いて証明し た。この非置換アミノ基はCHO細胞がつくるHSには見いだされ なかった。そして、L-セレクチンとカルシウム依存的に結合す るHS糖鎖の中にこの特異的構造が豊富に含まれていた。おもし ろいことに、市販のへパリンは内皮細胞からのHSに比べ、L-七 レクチンと強く結合する糖鎖がはるかに少ない。へパリンは一 般的にHSよりも硫酸化度やイズロン酸含量がはるかに高いが、 非置換アミノ基はほとんど含んでいない。このように、内皮細 胞由来HSはL-セレクチンと相互作用する非置換アミノ基を含ん だ特異的糖鎖配列をもっている。この著者たちは、L-セレクチ ンとの相互作用に関する硫酸化やエピマー化を含んだ糖鎖配列 やドメイン構造については何も示していない。しかしこの論文 は、HSの非置換アミノ基の存在は今まで認識されていた以上に 一般的現象で、特異的生物活性をもたらすのに必要な構造であ るかもしれない、という大変重要な知見を加えた。

市販へパリンから調製された 4 糖鎖以上のオリゴ糖断片は SLe ${ }^{\mathrm{x}}$ ウシシ血清アルブミンへのL-やP-セレクチンの結合をSLe ${ }^{\mathrm{X}}$ 自 身よりもはるかに低い濃度で阻害する [Nelson, R.M. et al. (1993) Blood, 82, 3253-3258]。このように、特異的構造をもったへパリ ン/HSはセレクチンの天然高親和性リガンドの一つであるかも知 机ない。将来この分野の研究は、疑いなくセレクチンとの結合 に関与するへパリン/HSの非置換アミノ基を含んだドメイン構造 そしてこのドメイン構造合成のための制御メカニズムの解明に 向けられていくであろう。医薬品応用の観点から、ヘパリン様 分子はセレクチンの阻害剂としてシアル酸やフコースを含むポ リラクトサミンより、より有効な素材となるかもし札ない。

生化学工業株式会社・東京研究所

石原 雅之 